This is an Accepted Manuscript of a book chapter published by Routledge in "EU Security Strategies: Extending the EU System of Security Governance" on 06 (ebook) and 11 (hardback) December 2017, available online: http://www.routledge.com/EU-Security-StrategiesExtending-the-EU-System-of-Security-Governance/Economides-

Sperling/p/book/9781138210417 


\title{
9 Securing borders, saving migrants: the EU's security dilemma in the twenty-first century
}

\author{
Michela Ceccorulli and Sonia Lucarelli
}

\section{Introduction}

The European Union (EU) has paid increasing attention to migration as a security issue. Migration recently figured as among its ten policy priorities in the medium term (Juncker 2014) and has undoubtedly become a strategic concern for the EU. As a consequence, the EU has tried to provide direction for its member states in this complex and multifaceted domain. With a considerable worsening of the demographic outlook for the EU, notably a declining and ageing population, migration could certainly turn into a golden opportunity for Europe: it could enable the European economies to sustain and improve their international competitiveness, pay for the costs of age-related entitlements, and more generally ignite those societies with the entrepreneurial energies of the young (Ceccorulli et al. 2015). This demographic future, in conjunction with uncontrolled migration occasioned by civil conflicts in Northern Africa and greater Middle East, indeed, requires strategic thinking by the EU. These challenges, particularly uncontrolled migration, are in no way unique to the EU or are any more tractable than elsewhere. EU member states have, however, conflicting ideas on what an efficient solution to those dilemmas may look like and for whom. The question is very sensitive, touching on issues of economic prosperity and national identity as it does, thereby rendering coherent political action even more difficult.

For the EU, though, coping with the challenge of migration has a double meaning: first, it implies envisaging solutions to a phenomenon that is here to stay. Second, it entails figuring out which kind of external security actor the EU is and is likely to be in the future: will it be an inwardlooking entity committed to 'securing' its homeland; or will it consider the security of migrants (and their rights) as equally relevant to the values it upholds and the external image it wants to project? Both objectives are strategic, as they pertain to the future of the EU and the European capability to face core challenges collectively. Hence, this chapter focuses on the key questions framing the contributions to this collection: What is the EU's ambition as a security actor in the migration domain? Is the EU an autonomous security actor vis-à-vis its member states in this domain? Is the EU strategy with respect to migration internally consistent and comprehensive? Does the EU deliver policies consistent with its security rhetoric and, if not, why and with what consequences?

To answer these questions, the first section looks at the progressive emancipation of migration as a policy domain acquiring strategic relevance. Attention is particularly devoted, 
respectively, to the security content of the EU documents on migration as well as its character as a discrete policy problem in EU security documents. The second section identifies the 2015 European Agenda on Migration (EAoM) as the document that comes closest to a full-blown migration strategy and analyses that document's security priorities, relevant actions planned and resources committed. We also consider the nature of the EU's actions intended to solve the security challenges envisaged: either generated by the EU for collective action or designed to reconcile the member states' different positions on migration. Towards that end, we draw on the EU-Turkey Statement, signed with Turkey in March 2016 (European Commission 2016g; European Council 2016b). The third section addresses the EU's effective capability to mitigate the security challenges identified in the EAoM. In the conclusion, we consider the role and nature of the EU as an autonomous security actor in the policy domain of migration.

\section{Migration and security in the EU documents}

What can be said about the EU's security concerns with respect to migration? Four main observations can be made. First, migration was a secondary EU policy preoccupation until recently. Second, migration has gradually been securitised, not as the result of an explicit act of securitisation of the issue per se, but as an ancillary and derivative component of policies within Justice and Home Affairs (JHA), particularly in response to internal and external challenges or the integrity of the Schengen area and freedom of movement. Consequently, some policy developments have not been the result of strategic planning on migration, but instead are part of a larger response to challenges to public safety (e.g. the terrorist attacks in Madrid and London). Nonetheless, the final observation is that the indirect path of institutional and political developments in the area of migration has eventually affected the subsequent choices that have been made when migration emerged as a discrete security concern.

After JHA was inserted into the EU framework and the EU was given an explicit competence on the matter with the Amsterdam Treaty, migration was always considered to be a part of the JHA package. The strategic relevance of this area was first established in the Tampere Council of October 1999, which kick-started multi-annual programming on JHA and de facto turned the ambition of creating an area of freedom, security and justice into an EU objective per se, and not as a flanking measure of the single market (Kaunert 2005). The Tampere Council Conclusions strongly underscored the necessity to develop a common policy on migration and asylum (European Council 1999). Yet, the policy innovation observed in Tampere was neither complemented with concrete actions nor replicated by the two successor JHA Programmes, the Hague Programme (2004-2009) and the Stockholm Programme (2010-2014). Yet a close reading of the Stockholm programme indicated that migration was of increasing relevance as a standalone issue (European Council 2009).

The terrorist attacks of Madrid (2004) and London (2005) foreshadowed the transition of migration into a security concern, albeit as a by-product of renewed concerns over the ability of 
the EU to control its common external border. The Hague Programme, delivered after the terrorist attacks in Madrid, opened by claiming that 'Freedom, justice, control at the external borders, internal security and the prevention of terrorism should ... be considered indivisible within the Union as a whole' (European Council 2005a: 3-4). While legislation progressed at slow pace regarding coordination efforts among member states on the asylum and migration fronts, the EU border control agency, Frontex, started its activities in 2005 and gradually has assumed an increasing relevance for a set of variegated JHA policies: anti-smuggling operations, the control of the external borders of the $\mathrm{EU}$, return programmes and risk assessments. Those policies, for some authors, represent the securitisation of migration (Neal 2009; Léonard 2010). Seemingly, the security dimension attached to the JHA package led to the adoption of the Strategy for the External Dimension of JHA (European Council 2005b). This strategy linked the internal and external dimensions of security consistent with the goals of the European Security Strategy (EES) (European Council 2005b: 4). ${ }^{1}$

The Treaty of Lisbon (2009) and the European Pact on Immigration and Asylum (European Council 2008a) provided a 'new impetus' for developing a common EU policy by creating a specific policy space for reflections on migration and asylum. A further, fundamental impetus for the development of a comprehensive EU migration policy came in the aftermath of the 2011 Arab Spring. The Arab Spring constituted the tipping point in the policy domain of migration, made manifest in the new Global Approach to Migration and Mobility of 2011. It claimed that 'migration is now firmly at the top of the European Union's political agenda' and dialogue on migration mobility and security with North African countries was urgently required (European Commission 2011: 2). Orderly movements, a 'core strategic interest' of the EU, were the key priority of this new approach as well as the guiding principle of future approaches to the matter. The potential for a chaotic, uncontrolled and massive influx of migrants would constitute a challenge for the EU and possibly irreparably harm the integrity and resilience of the social fabric. It is through this lens, for example, that one has to evaluate the recent 'hotspot approach' whereby national authorities and European agencies (the European Asylum Support Office (EASO), Frontex and Europol) work together in order 'to swiftly identify, register, and fingerprint incoming migrants' (European Commission 2015a), as well as the preference for resettlement plans; namely, the orderly transfer of refugees from third countries to member states to ensure the legal entry of migrants and asylum seekers into the EU.

The tragic deaths of migrants in the Mediterranean Sea, the massive arrivals of migrants on the Italian and later on the Greek coasts, the repeated tension between Italy and France for the control of the border between the two countries at Ventimiglia, the worsening of the Syrian conflict and the masses of refugees that it produced via the Balkan route since 2015, have all contributed to the increasing reliance on the language of emergency in public debates on migration. The pressure for a European response to the crisis arose from the imposition of 
temporary border controls between countries of the Schengen area and the reappearance of physical barriers (if not walls) on the external borders to stop the flow of migrants. It was in this context that the EAoM was delivered. The Agenda may have been a response to the migration crisis, but it was nonetheless timely and long overdue. As a document on the relevance, potential security dimensions and policy responses to the challenge of migration, the EAoM (European Commission 2015a), it is without question a strategic document to be read jointly with the new Internal Security Strategy (ISS).

\section{Migration in the security strategies}

Migration was scarcely mentioned in the 2003 ESS (Council of the EU 2003). Migrant outflows to Europe were only identified as consequence of competition for natural resources (and the acceleration of climate change). But illegal migration was a security concern owing to its indirect link to organised crime, identified as a 'key threat' with possible links to terrorism, that engaged in 'cross-border trafficking in drugs, women, illegal migrants and weapons' (Council of the EU 2003: 3-4). The Report on the Implementation of the ESS (European Council 2008b) again related migration flows to environmental challenges, state failure and organised crime and called for a more robust connection between internal and external strategies and instruments to protect the EU's security. In the 2008 Report, migration was partly given its own security standing: it identified illegal immigration as one of the most complex security challenges in the Mediterranean, a key strategic area for the EU (ibid.: 7).

Although migration was never mentioned in the 2005 EU Counter-Terrorism Strategy, it did devote attention to border protection and control (European Council 2005c). In order 'to combat terrorism globally, and make Europe safer, allowing its peoples to live in freedom, security and justice, within a framework that respects human rights', the 2005 Strategy averred that the EU needed to be able to prevent terrorism, protect from it, disrupt it globally and respond to its threat. Those goals, in turn, required the EU to undertake policies that would protect the EU's external borders in order to ensure the integrity of the Schengen space and foster an area of freedom, security and justice (see Collyer 2006). External border management was understood as the trait d'union between the inflow of migrants and internal security (Guild 2003; Monar 2006). The methods conceived to counter terrorism, such as biometric information on identity and travel documents, risk assessment through Frontex, the Visa Information System and the secondgeneration Schengen Information System for the sharing of information, strongly suggest that migration management had become a critical component of any EU security strategy (European Council 2005c: 10). These methods, therefore, were powerful performative devices facilitating the securitysation of migration qua migration (Ardau and Huysmans 2014: 604).

The first EU 'Internal Security Strategy' in 2010 was inspired by the need to compensate for the blurring between external and internal security dynamics as the multiplicity and interconnectedness of transnational challenges testified. Here again, migration was not mentioned 
as an explicit threat as were organised crime or terrorism, but strengthening the management of the external border and achieving border security were identified as strategic objectives (European Commission 2010a). The population disruptions attending the Arab Spring uprisings, and the increased inflows of migrants and asylum seekers later on, compelled the EU and its member states to treat migration as a component of the security agenda. Subsequently, migration was inserted into EU security strategies. The European Agenda on Security (EAS) of April 2015 (on internal security) (European Commission 2015c) and the EU Global Strategy (EUGS) of 2016 (on global security) consolidated the strategic relevance of migration. The 2010 ISS and the EAS did not consider 'external borders' in conjunction with terrorism, organised crime and cybercrime, but instead treated migration as a specific and discrete security concern that was included in the 2015 EAoM. Hence, the EAoM complemented the EAS by addressing the smuggling of migrants, the trafficking in human beings, social cohesion and border management all 'issues directly relevant to security' (ibid.: 4).

Migration was also frequently mentioned in the newest EU security document, the EUGS (EEAS 2016b; Ceccorulli and Lucarelli, 2017). Interestingly, and connected to the demographic policy paradox that migration poses for Europe, the first reference to mobility in the strategy emphasised the importance of migration for improving lives of citizens in both third countries and the EU. This strongly suggests that migration is recognised as a strategic opportunity, articulated as such in the 2020 Strategy for Growth (European Commission 2010b). The attention to and recognition of the opportunities that might arise from migration are very relevant to EU policy initiatives and should be under- lined to avoid the impression that the EU has exclusively securitised migration. As a matter of fact, migration is never present as a 'threat' in its own terms in EU documents, as the 'security strategic language' would require. Rather, it is referenced as 'a challenge' (ibid.).

The EUGS linked the success of the EU in meeting its key strategic objectives to ensuring that external policies and instruments were 'migration-sensitive' and consistent with internal policy initiatives. Indeed, the most relevant novelty in the EUGS was the inclusion of a sub-section specifically dedicated to migration and linked to the concept of 'resilience'. The EUGS paid attention to policies that could mitigate migrant flows from origin and transit countries. The strategy, which recommended that the EU and the member states employ a variegated set of measures to tackle the root causes of forced migration, to better share migration management and to jointly fight trans-border crime (EEAS 2016b: 27), placed an emphasis on humanitarian assistance and capacity-building as well as on readmission and return. It is worth noting that when the EUGS spoke of the necessity for a more effective common European asylum system respectful of protection seekers' rights, the EU underlined that their arrival should also be regulated and legal (ibid.: 28), a logic already evident in the EU-Turkey Statement of 18 March 2016 (see below). 
To conclude, migration as a standalone issue has only recently been considered of strategic relevance for the EU's security broadly conceived. EU documents on migration and security strategies reveal an ever-growing preoccupation with migration as a relevant issue on its own terms (and eventually emerging as a policy priority for the EU) and have linked migration with security to both the protection of the EU territory from uncontrolled flows as well as the safety of migrants.

\section{Migration and strategic practices}

The EAoM expanded the understanding of border security that had dominated EU discourse prior to 2015. The EU expanded border security discourse included border protection as well as the duty to avert the further loss of life by migrants and refugees (European Commission 2015a). This expansion of the EU remit reflected, in turn, the calculation that the duty to avert the further loss of life was a critical component of its own values and its existing international commitments. Hence, saving lives and securing borders were the two key security imperatives shaping EU policy in the immediate and into the longer term.

These two security imperatives, if realised, would also enable the EU to reap the possible opportunities offered by migration. But as a matter of policy, it inevitably required 'coordinated action at the European level ... and a consistent and clear common policy' (ibid.: 2). But how did the EU plan to reconcile those policy imperatives? What policy instruments were available to do so? The EAoM identified a range of EU instruments that could serve the twin ambitions of the EU. For example, the document explained that 'FRONTEX can fulfil its dual role of coordinating operational border support to Member States under pressure, and helping to save the lives of migrants at sea' (ibid.: 3); that anti- smuggling initiatives are 'first and foremost a way to prevent the exploitation of migrants by criminal networks', but can also deter irregular immigration (ibid.: 8). Similarly, the proposed EU Border and Coast Guard system would explicitly fulfil the tasks of 'saving lives and securing maritime borders' (ibid.: 10).

The EAoM, then, had the double objective of coping with an ongoing crisis while providing guidelines to avert similar crises in the future and of making the EU response more effective in future occurrences (and in this sense it is a strategic document). Several measures were planned for the short term to meet the two security priorities identified: improve search and rescue efforts through Frontex, increase funds for first states of reception, target criminal smuggling networks, and improve relations with third countries to halt dangerous journeys. The redistribution of asylum seekers in 'clear need of international protection' among member states (relocation) was also included, but in conjunction with the introduction of the aforementioned 'hotspot approach' (ibid.).

The strategic relevance of facing the migration crisis was also apparent in the resources committed, which have been significantly increased over time. With respect to the initial allocation of funds under the Asylum, Migration and Integration Fund (AMIF) and the Internal 
Security Fund (ISF) (the main financial instruments for migration and internal security) planned for 2015 and 2016, the EU allocated €4.6 billion and an additional €2.2 billion to meet personnel, equipment and infrastructure requirements (European Commission 2016b). Greece, for example, received strong support under the EU budget, with €352 million allocated for emergency assistance on top of the amount already received under AMIF and ISF for 2014-2020 (European Commission 2016c). Moreover, the EU allocated $€ 500$ million to a Trust Fund for Syria and $€ 1.8$ billion to an EU Emergency Trust Fund for Africa (European Commission 2016b). ${ }^{2}$ The EU pledged $€ 1$ billion to Jordan and Lebanon in February 2016 to help these countries meet the staggering costs of hosting refugees in their territories (European Commission 2016d). In turn, Turkey has been a special recipient of EU funds: an initial €1 billion was allocated as 'Facility for Refugees' well before the March Statement was signed to support refugees in the country; for 2016-2017, the Fund has at disposal €3 billion, of which €1 billion is drawn from the EU budget and the balance supplied by the member states (European Commission 2016e). For the long term, the European Union was (and still is) examining proposals that would more effectively solve or manage potential challenges at the EU level, given that the Schengen system would not allow for unilateral solutions. Among the proposals are those to envisage a permanent quota redistribution scheme in case of exceptional and massive arrivals, the definition of an EU resettlement scheme, the revision of the Dublin system for the examination of asylum requests, the creation of European Border and Coast Guard (running since October 2016), and the establishment of more thorough relations with origin and transit states.

Both for the short and the long run, though, the EU has struggled to emerge as a decisive and ambitious actor. In most cases the measures undertaken have tried to reconcile member states' different positions on migration and asylum: the 'relocation-hotspot' tandem was intended partly to alleviate the pressure on the first arrival countries in the EU and partly to oblige these same countries to be more responsive with respect to their obligations under the Dublin Regulation. Furthermore, member states have not provided the level of resources pledged and, notwithstanding the many infringements procedures issued by the EU, member states have failed to fully implement the measures already agreed (the relocation system is mandatory but has not been applied as expected) and set themselves against 'durable' solutions that would impinge upon their 'national prerogatives'. While the EU tries to get the upper hand by proposing to transform Directives on asylum into legally binding Regulations, the latter seem to be tailored more to meet the needs of the member states for restrictive policies rather than to revise an asylum system that does not offer much protection to persons in need.

Against this background, which reveals intractable limitations on the EU's acquisition of a more assertive and inspired role (which has nonetheless been greater than any time prior to 2015), the EU has found it easier to implement measures aimed at protecting its borders in cases of massive arrivals (e.g. European Border and Coast Guard) or in engaging third countries 
in the handling of the issue (the Statement with Turkey of March 2016 is only a pilot project for what promises to be a working scheme for the future, see below). None of these approaches is new to the Union. Critics of the EU migration policy have regarded the EU's approach, centred as it is on border protection and agreements with third countries to keep migrants out of Europe, as a form of self-protection and the externalisation of the control of migration flows privileges 'secure borders' (Balleix 2016).

Therefore, it is possible to observe 'structural limitations of EU migration policies and the tools at its disposal' (European Commission 2015a: 6). The most relevant relate to competences (shared between the EU and the member states) and limited resources, but also to the lack of a common sense of shared responsibilities on the matter among member states, which can be translated as the lack of that famous 'we-feel' that nurtured the early phases of the European integration project. In the next section, we investigate this aspect more deeply. Our analysis underlines that the failure to jointly agree on and implement measures on migration has reinforced a security understanding of the phenomenon (see Jeandesboz and Pallister-Wilkins 2016) and has led to externalisation practices and related practices, as exemplified by the EUTurkey deal.

\section{Externalising internal security}

The European Council and Turkey signed, on 18 March 2016, a political Statement that struck a deal whereby the principals deepened relations in order to cope with the common migration crisis (European Council 2016a). Bilateral talks between the EU and Turkey commenced in May 2015 (while previous agreements on mobility dated back to 2013), and in mid-October an Action Plan was signed. By 2015, Turkey had turned into the principal transit route to the EU for migrants and refugees, mainly but not exclusively escaping the Syrian civil conflict, and has been identified as a key interlocutor in the effort to control the massive and unregulated migration to the EU. The objective of the Statement was to 'break the business model of smugglers and offer migrants an alternative to putting their lives at risk' (European Council 2016b). A component of that plan was halting the irregular immigration from Turkey. In fact, the deal completely sealed the EU's external border of the EU. The message conveyed was that no illegal routes (of irregular immigrants but also of asylum seekers) into the EU would be accepted. The mechanism envisaged was rather staggering in its simplicity: all new (starting from 20 March 2016) irregular immigrants arriving in Greece from Turkey would be sent back and, most importantly, the EU would admit one Syrian refugee for every Syrian who arrived as an irregular migrant in Greece and returned to Turkey. The EU, committed to pay €3 billion under the Facility for Refugees in Turkey (of this, less than $€ 500$ was effectively disbursed in late 2016) (see European Commission 2016e). The EU also offered to cover the costs of the return operations of irregular immigrants from Greece. 
Greece, in turn, would be given full support to deeply revise and improve its asylum structures (European Council 2016b). The deal has been widely criticised from different angles: concerning its legal basis, its supposed effectiveness and, most importantly, for Turkey's improved status as a 'safe country' and more generally for the adverse repercussions on migrants' rights and faith (see Amnesty International 2016; Collett 2016). The EU-Turkey Statement was made necessary by the inability of member states to properly fulfil their asylum obligations, particularly the relocation plan. Indeed, it was not the first time the EU had (unsuccessfully) tried to trigger solidarity among member states on migration: the 2001 Directive on Temporary Protection to deal with mass influxes of displaced persons inspired by the Yugoslavia conflict and resulting displacement of people was never enacted.

Relocation consisted of a distribution scheme among the member states based on the size of their national population, their country's total Gross Domestic Product, their average number of spontaneous applications and number of resettled refugees, and their unemployment rate. Each member state was then responsible for the examination of the applications of the persons assigned. Relocation was hence aimed to alleviate the burden of countries strongly affected by arrivals, notably Italy and Greece. But Hungary was also identified as strongly affected country in September 2015 and hence became a potential beneficiary of the relocation plan. However, Hungary rejected the offer and affirmed that massive arrivals in the country were not to be explained by the fact that Hungary was a state of first arrival (as Italy and Greece), but by Greece's failure to meet its duty consistent with the Dublin regulation (Zalan 2015, 2016).

The EU member states were slow in enacting the relocation scheme (European Commission 2016a) and notwithstanding the mandatory nature of the provision, none felt particularly eager to implement it. Hungary and Slovakia appealed to the European Court of Justice against the plan. Similar proposals, such as the one to have a 'permanent' distribution system, were strongly opposed. The Visegrad states reiterated their refusal to have any permanent relocation scheme by making it clear that immigration policy should remain a matter of national sovereignty (Rettman 2016). Hungary held a referendum on the issue in October 2016, the result of which was invalidated because the majority of Hungarians did not vote as is necessary. Moreover, the failure of the frontline states (and in particular Greece) to comply with the Dublin Regulation on the registration of incoming migrants triggered multiple reactions in the transit and receiving countries, as in the case of Hungary. While talks about excluding Greece from Schengen were made, several countries (Germany, Austria, Denmark, Sweden, Norway, France) reintroduced controls at certain internal borders (Traub 2016), tightened asylum legislation (Nielsen 2016a), put 'caps' on persons allowed into their own territories (Austria), or even built physical structures to hamper the inflow of immigrants, as Hungary did at the border with Serbia and Croatia. Eventually, these measures led the Western Balkan states on the transit route to adopt similarly restrictive measures. The situation was particularly troublesome since it ran the risk of creating a 
bottleneck in Greece, effectively stranding migrants there and at the same time jeopardised the Schengen system guaranteeing the free movement of people. The terrorist attacks in Paris worsened the situation after explicitly requesting the strengthening of con- trols at 'the most exposed external borders' - the Greek-Turkish border - to close the 'main point of irregular entries into the EU' (Maurice 2015).

The EU, unable to make up for its shortcomings and to close the loopholes in migration policy, considered the survival of Schengen at risk. Consequently, the EU opted to mitigate the causes of internal disagreement. But that decision had adverse security implications.

\section{What internal security?}

There are three major - and neglected - 'internal' challenges to crafting an EU security policy as it touches upon migration: there are deep divisions among the member states with respect to their receptivity of migrants; a lack of solidarity among member states during migration crises as have occurred in the recent past; and policy violations of EU values that constitute a core part of the European identity.

Far from having solved the challenge posed by uncontrolled migration, the EU attempt to craft a set of policies addressing the complexities of migration in the Mediterranean Basin have created divisions among member states. There is currently no fixed consensus on how migration should be understood or the most effective governance response to it. In addition to the acknowledged division between 'old' and 'new' members, there are other unprecedented policy changes in individual member states, particularly the policy U-turn of traditionally welcoming countries such as Sweden and Norway. Much more than the euro crisis, the last two years have revealed completely different interpretations of irregular migration and the appropriate policy response among the member states. Some member states understand 'search and rescue' operations to save the lives of migrants as a duty Europe cannot escape (e.g. Italy), while for others (e.g. the United Kingdom) those operations are no more than 'pull factors' and migrants' lives would better be saved by preventing them from embarking on such danger- ous journeys (Travis 2014). Many member states have blamed German Chancellor Angela Merkel's 'open door' policy to Syrian refugees, while others have not hesitated to link refugees' arrival with the enhanced probability of terrorist attacks (Cienski 2016).

The lack of solidarity among member states is the second most evident product of the migration crisis; it represents the potential disruptive impact that exogenous developments can have on the EU. As noted, just when solidarity was most needed in a time of crisis, the member states have fallen short. This absence of solidarity may be illustrated by the burden exclusively borne by Italy with the Mare Nostrum operation (the unilateral search and rescue operation led by Italy in the Mediterranean between 2013 and 2014). Member states have not been hesitant to pass the buck or undertake unilateral positions to further their own national interest in preventing migrants from entering their territory and to yield to the demands of an increasingly xenophobic 
electorate. These reactions have come at a high price and to the detriment of the common European project. As a matter of fact, the free movement of persons has been too easily put into question together with the possible exclusion of a member state (Greece) from the Schengen system. These particular migration challenges do not categorise migrants as potential security risks; most accept that irregular immigration will remain a problem into the foreseeable future, given demographic and other trends. Instead, the absence of a strategic thinking on migration with all its multiple facets and a failure to link it to the common EU project have turned the migration crisis and its knock-on effects into one of the most formidable challenges not only to the EU role as a security provider, but also to the EU's exist- ence as a unitary actor in the international landscape. As a result, the ability of the EU to follow up on any other security threat places into question the limits and possibilities of the EU as a security actor.

Finally, the EU seems to have not fully grasped the negative consequences arising from possible violations of some values and principles for its own credibility in the international landscape, especially if this behaviour is going to be replicated with other countries and risks becoming the new normality. A distinctive trait of the EU's self-representation, one on which the EU has built its legitimacy inside and outside the Union, is the respect of core values, particularly those listed in its Charter of Fundamental Rights (among which human dignity, right to life, prohibition of torture and inhuman or degrading treatment or punishment, right to liberty and security, right to asylum, non-discrimination) has been regarded as the defining characteristics of the EU's specific political identity (Lucarelli and Manners 2006). The transposition of those values into political conduct and also into foreign policy has been recalled again and again in EU documents. But the failure to cope with the EU's core values in the management of issues touching on human security, such as migration, delegitimises the EU more than it would delegitimise any traditional international actor.

\section{Delivering on security objectives: an evaluation}

With a view to considering whether the EU has, thus far, been able to mitigate the security challenges identified in the EAoM, we now assess if the EU has been successful in achieving its two policy objectives: (1) saving the lives of migrants; and (2) securing the common external border. Finally, we consider whether the EU's stance vis-à-vis these two objectives has (thus far) had a mitigating effect on the challenge posed by mitigation to European security.

If it is undeniable that securing the lives of migrants has found a central space in EU's documents (far more than in previous documents where it was scarcely and swiftly mentioned), it is also fair to affirm that the EU has failed to deliver on this rhetoric. The EU has not been able to substitute the 'search and rescue' operation undertaken by Italy in late 2013 (Mare Nostrum), owing to the absence of consent among its member states, but also and most importantly because it had no power to act independently of the member states. The EU recognized early in the crisis that 'collective European policy on the matter has fallen short' (European Commission 
2015a: 2). In an attempt to partly compensate for the lack of a more assertive action in this realm and to cover the same geographic space as did the Italian search and rescue operation, the EU strengthened and expanded Frontex operations already in place. ${ }^{3}$

Admiral De Giorgi (former Chief of the Italian Navy) made it clear that it would be quite easy for a military ship to engage in search and rescue operations given the advanced command and control systems at the disposal of European naval forces and given their constant presence at sea (De Giorgi 2015). Hence, the CSDP Operation EUNAVFOR MED, launched in May 2015 as an anti-smuggling effort, gave substance to the concept of 'duality' underlined in the new EUSG: the military equipment increasingly undertaking the dual functions of creating dedicated reception spaces for migrants (sewage systems, device for electricity provision, large space, etc.) and contributing to the saving of migrant lives with reliance upon advanced surveillance, information, and search and rescue systems (ibid.). Operation EUNAVFOR MED has taken centre stage in EU's interpretation of how 'saving lives' could be achieved and indeed EUNAVFOR MED has rescued many migrants at sea, including the Somali woman who gave birth on the German frigate Schleswig-Holstein. ${ }^{4}$

Yet, two additional remarks must be made: first, the security concerns ultimately leading to the adoption of the operation were not limited to the need to save migrants. Possible terrorist infiltration and overall instability in Libya (which in turn contributed to the migrant outflows) were two main security concerns of the EU's member states. Since June 2016, for example, EUNAVFOR MED received a mandate to train the Libyan coast guard and navy and to contribute to enforce the UN arms embargo in the high seas off Libya. Second, the CSDP Operation has been equally seen as forcing smugglers and migrants towards more dangerous routes or, even worse, to remain in Libya (Duranti 2015). It is telling that the Italian supporters of the Operation are highly concentrated among partisans of the Northern League, an Italian political party that is openly and fiercely opposed to immigration. They consider the CSDP operation to be a (most welcome) naval blockade (Divina 2015) and the destruction of smugglers' boats as a way to prevent the departure of migrants from Northern Africa (Vito 2015). Indeed, the Operation has been remarkably successful and has saved many lives since its launch (EEAS 2016a). Yet, the number of migrants who perished at sea in 2016 rose sharply as compared to 2015, even though according to the International Organization for Migration (IOM), the number of arrivals in Italy has not differed that much (Nielsen 2016b).

Aside from this specific aspect there are wider considerations one can make with reference to the security objective envisaged by the Union (protecting migrants' lives). Attention has already been paid to the recent violation of human rights, which may affect the security of migrants in the case of the agreement with Turkey. Similar reasoning can be made for a series of actions undertaken, such as, for example, the attempt to define a list of 'safe countries of origin' which are dubious at best, return and readmission operations, and the patrolling and surveillance 
systems that may redirect migrants towards riskier journeys. Opening more legal channels into the EU, such as a wider and permanent EU resettlement commitment (which only now commits the EU to resettle 20,000 refugees every year until 2020), is an effective way to save migrants' lives but has also failed to gain the support of many member states.

Turning to the second security objective of the EAoM, much has been said on the long-standing emphasis on the aim of 'securing borders'. The most recent development in this regard is the creation of a European Border and Coast Guard in June 2016 and its activation in October 2016. Building on Frontex and relying on member state authorities responsible for border management, the creation of a European Border and Coast Guard tried to compensate for the Agency's weakness, including an inability to procure equipment, no operational staff and no autonomy over return and border management operations (European Commission 2015d). Notwithstanding these efforts, it is hard to tell whether the EU would meet the objective of secure borders, given the nature of the challenges ahead. Indeed, some 'migration corridors' have been quite successfully closed, but that closure has inevitably had the effect of merely diverting the migratory flow. Also, 'externalisation' attempts have often proven scarcely effective (Ceccorulli 2014) since EU institutions are 'never in total control of those outcomes' (Collyer 2016: 607; Lavenex and Wichmann 2009). More importantly, perhaps, is the consideration that the EU would ultimately fail to meet its security objectives (securing the lives of migrants and securing the EU's common border) if it remains incapable of addressing the underlying causes of mass migration: conflicts, civil unrest, environmental degradation, economic opportunities or simple demographic factors. The new EUGS has undoubtedly started to seriously consider migration as a strategic issue in this sense for EU (and migrant) security.

\section{Conclusion}

In recent years, the EU has placed increased attention on uncontrolled migratory flows into Europe, has continually fine-tuned its policy approach to the phenomenon, and produced an impressive amount of legislation. Increasingly, migration has acquired a significant strategic importance for the EU. Although the EU has been mindful of the positive and necessary contribution that migrants can make to ageing European societies, it has nonetheless focused attention on the security ramifications of migration. The focus of migration policy has shifted from the task of preserving the EU's border security to protecting European societies from massive and unregulated migration that could potentially destabilise European societies and undermine the Schengen system to preventing the loss of life of migrants crossing the Mediterranean or their exploitation by smugglers. This new and comprehensive attention to uncontrolled migration was ascribed enormous prominence in the recent EU Global Strategy.

Against this background, we can now answer in the affirmative the first question posed in the introductory Chapter 1 : has the EU realised its ambition to emerge as a security actor in this policy domain? The EU has upgraded migration and it now ranks among its most urgent of 
security concerns; it has accelerated a legislative path that had languished for many years at the EU level; and it has proposed and implemented initiatives on the security aspects of migration. These initiatives include the setting up of operations to rescue migrants (EUNAVFOR MED), providing increased opportunities for 'safe arrivals' (resettlement plans), fighting human trafficking and smuggling (European Commission 2015b), implementing auxiliary measures to further secure borders (e.g. European Border and Coast Guard), and mitigating migrant flows with bilateral arrangements with transit states (EU-Turkey Statement). Most importantly, the issuing of the EAoM in May 2015 provided direction over these security objectives, set different schedules for achieving the different security aims related to migration and specified the lines of action and level of funding required to meet these objectives.

Do these policy initiatives provide the empirical evidence supporting the claim that the EU is an autonomous security actor vis-à-vis its member states? The short answer is no. In fact, as noted several times in this chapter, the member states have circumscribed the EU's policy autonomy. The EU does not enjoy full competence in the realm of migration; moreover, even in those areas in which the EU has been called to play a more prominent and relevant role (as in asylum and irregular immigration), it has not been able to create a 'collective will' among the member states. In some cases, the EU has replaced pre-existing national operations (e.g. the Italian Operation Mare Nostrum) with much more limited follow-on operations (e.g. Triton). Moreover, the EU has not been able to craft an effective or binding solution to the 'refugee crisis': the relocation plan, proposed and agreed by a qualified majority in the Council, could only work if the member states committed to it fully and in a timely manner - a requirement not yet met. The EU partly succeeded in the attempt to achieve more autonomy in securing the common border through the creation of the European Border and Coast Guard Agency. However, the Agency is much less ambitious and autonomous than originally planned. Instead, the EU has succeeded in reducing irregular immigration from the Balkan route through the EU-Turkey Statement, although even in this case the agreement was negotiated by member states rather than EU institutions.

It is difficult to assess whether the EU migration strategy is internally consistent and comprehensive. It would certainly be difficult to affirm that the strategy is comprehensive. Indeed, both the EAoM and the EUGS make an attempt to account jointly for this policy domain in all its variegated aspects. However, the EU lacks competences in all migration domains and therefore its action is inevit- ably concentrated in those policy domains where it has more power to act (e.g. securing its borders and engaging in relations with third countries). Commission attempts to increase the legal opportunities for migrants to reach the EU or efforts to speed up the pace and the entity of resettlement programmes or proposals to revise the internal functioning of the Common Asylum System have encountered a great deal of opposition from the member states. If not comprehensive, is the EU strategy on migration at least internally consistent? 
Overall, it can be affirmed that the EU migration strategy has been internally consistent through time and has mainly sought to reduce (and possibly prevent) irregular inflows of migrants and asylum seekers into the EU. The additional task of saving lives has been gradually added to the EU's priorities (the EU had been virtually silent regarding migrants' deaths at sea before 2013). In order to limit the number of arrivals to the European territory (an objective already identified at least a decade ago), the EU has particularly invested in improving relations with third countries towards jointly managing the problem of migration. Such a strategy followed the path of the 'external dimension' of JHA issued already in 2005 (European Council 2005b). The same strategy characterises the EUGS and is manifest in other EU foreign policies.

However, if the migration strategies adopted over time and domains are consistent, the arguments used by the EU to explain them are often not. Hence - and here we come to the final question posed in the Preface - it is difficult to affirm that the EU's policy is consistent with its rhetoric. Indeed, it cannot be denied that the EU has adopted measures consistent with the proclaimed aim to secure borders and to protect the Schengen area. The EU's policy rhetoric has increasingly shifted emphasis to the aim of saving migrants' lives; it now enjoys a rhetorical status equal to that of protecting the EU's borders. If to this rhetoric one adds the frequent emphasis in the EU documents on the need to protect human rights, some of the measures adopted in the EU's management of migration are rhetorically inconsistent, if not incoherent. As an example, the EU's concern for the maintenance of orderly and legal arrivals has been faced with the creation of quasi-legal provisions endorsed in 'non-agreements' with third countries (as in the case of Turkey), which are in fact incompatible with the goal of respecting the migrants' safety and rights - whether they are asylum seekers or not. Ultimately, the security objectives underlined by the EU (save lives and protect borders) are difficult to reconcile, particularly because of the EU's incomplete security 'actorness' in this domain. Eventually, the overall effect is frequently a stark divorce between what the EU says (which mostly derives from the values it supports) and what it actually does. The inability to reconcile rhetoric and action works to the detriment of the EU as a security actor-in-the-making.

\section{Notes}

1 According to Francesca Longo, the process of externalisation of the JHA 'is to be framed in the EU broader strategy to link domestic and external security and in the re- definition of the concept and practices of security' (2013: 45), increasingly intended as 'holistic', weakening both theoretically and practically the divide between internal and external security.

2 The aim of the Trust Fund is to pool resources from many donors, aimed at increasing stability in the Sahel region, in the Lake Chad area, in the Horn of Africa and in North Africa (other regions are eligible). As of 3 November 2016, the Netherlands, Italy and Belgium have pledged the highest contributions ( $€ 15$ million, $€ 10$ million, $€ 10$ million respectively); other member states have pledged much less. These amounts are to be added to $€ 1.8$ billion committed by the EU through different EU financial instruments, see http://ec.europa.eu/europeaid/sites/devco/files/pledged-contributionseutf03112016 en.pdf

3 Operation Mare Nostrum had cost Italy €114 million (€9.5 million per month); Triton, the Frontex operation that started after the dismissal of the Italian operation ran with a budget of $€ 3$ million per month. Indeed, that was not the only operation Frontex was running in the broader Mediterranean area. Far more significant is the fact that it operated much 
closer to Italian coasts with respect to Mare Nostrum, which instead oper- ated on the high seas, very close to Libyan territorial waters, see www.corriere.it/cronache/14 ottobre 31/mare-nostrum-chiude-battenti-100mila-salvatima-pesano-morti-9566507e-611b-11e4-938d-44e9b2056a93.shtml

4 The Somali child was named Sophia; Federica Mogherini suggested that EUNAVFOR MED be rechristened as Operation Sophia as a testimony to the humanitarian purpose of the CSDP operation.

\section{References}

Amnesty International. 2016. Turkey: No Safe Refuge. Asylum Seekers and Refugees Denied Effective Protection in Turkey. London: Amnesty International.

Ardau, Claudia and Jef Huysmans. 2014. 'Critical Methods in International Relations: The Politics of Techniques, Devices and Acts'. European Journal of International Relations, 20 (3): 596-619. doi:10.1177/1354066112474479.

Balleix, Corinne. 2016. 'What Type of Reform of the Common European Asylum Regime Are We Heading Toward?' European Issue Policy Paper, No. 400. Paris: Fondation Robert Schuman.

Ceccorulli, Michela. 2014. Framing Irregular Immigration in Security Terms: The Case of Libya. Florence: Firenze University Press.

Ceccorulli, Michela, Enrico Fassi and Sonia Lucarelli. 2015. 'Europe's “Depopul- Ageing” Bomb?' Global Affairs, 1 (1): 81-91. doi:10.1080/23340460.2015.986701.

Ceccorulli, Michela and Sonia Lucarelli. 2017. 'The Many Facets of Migration in the EU Global Strategy: Narratives, Strategic Priorities and Normative Dilemmas'. The Inter- national Spectator, 52 (3).

Cienski, Jan. 2016. 'Poland Slams Doors on Refugees'. Politico, 24 March. Available at: www.politico.eu/article/poland-slams-door-on-refugees-beata-szydlo/. (accessed 30 May 2017).

Collett, Elizabeth. 2016. 'The Paradox of the EU-Turkey Refugee Deal'. Migration Policy Institute. Available at: www.migrationpolicy.org/news/paradox-eu-Turkey- refugee-deal (accessed 30 May 2017).

Collyer, Michael. 2006. 'Migrants, Migration and Security Paradigms: Constraints and Opportunities'. Mediterranean Politics, 11 (2): 255-270. doi:10.1080/13629390600682974.

Collyer, Michael. 2016. 'Geopolitics as a Migration Governance Strategy: European Union Bilateral Relations with Southern Mediterranean Countries'. Journal of Ethnic and Migration Studies, 42 (4): 606-624. doi:10.1080/1369183X.2015.1106111.

Council of the European Union. 2003. 'A Secure Europe in a Better World - European Security Strategy'. 12 December, Brussels. Available at: www.consilium.europa.eu/uedocs/cmsUpload/78367.pdf

de Giorgi, Giuseppe. 2015. 'Audizione del Capo di Stato Maggiore della Marina Militare, $1^{\circ}$ Commissione Permanente'. Resoconto Stenografico, XVII Legislatura. Italian Senate. 7 July, Rome.

Divina, Sergio. 2015 'Fascicolo Iter DDL S. 1997'. XVII Legislatura. Italian Senate. 22 July, Rome.

Duranti, Donatella. 2015. 'Sulla partecipazione dell'Italia all'operazione dell'Unione Europea nel Mediterraneo centromeridionale EUNAVFOR MED'. Commissioni Riunite: IV Camera e $4^{\circ}$ Senato. Italian Chamber of Deputies. 25 June, Rome.

EEAS (European External Action Service). 2016a. 'Over 20.000 Souls Saved by Eunav- for Med's Asset Since Mission Launch'. 20 July, Brussels. Available at: http://eeas.europa.eu/csdp/missions-and-operations/eunavfor$\underline{\mathrm{med} / \mathrm{news} / 2016072001 \mathrm{en} . \mathrm{htm}}$

EEAS (European External Action Service). 2016b. 'Shared Vision, Common Action: A Stronger Europe - A Global Strategy for the European Union's Foreign and Security Policy'. 28 June, Brussels. Available at: https://europa.eu/globalstrategy/sites/global-strategy/files/eugs review web.pdf

European Commission. 2010a. 'The EU Internal Security Strategy in Action: Five Steps Towards a More Secure Europe.' COM(2010) 673 final. 22 November, Brussels. Available at: http://eur-lex.europa.eu/legalcontent/EN/TXT/PDF/?uri=CELEX:52010DC0673\&from=EN

European Commission. 2010b. 'Europe 2020. A European Strategy for Smart, Sustain- able, Inclusive Growth'. $\operatorname{COM}(2010) 2020$ final. 3 March, Brussels. Available at: http://eur-lex.europa.eu/legalcontent/EN/TXT/PDF/?uri=CELEX:52010DC2020\&from=EN 
European Commission. 2011. 'The Global Approach to Migration and Mobility'. COM(2011) 743 final. 18 November, Brussels. Available at: http://eur-lex.europa.eu/legal-content/EN/TXT/PDF/?uri=CELEX:52011DC0743\&from=EN

European Commission. 2015a. 'A European Agenda on Migration'. COM(2015) 240 final. 13 May, Brussels. Available at: http://ec.europa.eu/dgs/home-affairs/what-we-do/policies/european-agenda-migration/backgroundinformation/docs/communication on the european agenda on migration en.pdf

European Commission. 2015b. 'EU Action Plan Against Migrant Smuggling 2015-2020'. COM(2015) 285 final. 27 May, Brussels. Available ht: htt//lec.europa.eu/antitrafficking/sites/antitrafficking/files/eu action plan against migrant smuggling en.pdf

European Commission. 2015c. 'The European Agenda on Security'. $\operatorname{COM(2015)~} 185$ final. 28 April, Brussels. Available at: http://ec.europa.eu/dgs/home-affairs/e-library/documents/basicdocuments/docs/eu agenda on security en.pdf

European Commission. 2015d. 'A European Border and Coast Guard to Protect Europe's External Border'. Press Release. 15 December, Strasbourg. Available at: http://europa.eu/rapid/press-release IP-15-6327 en.htm

European Commission. 2016a. 'Implementing the European Agenda on Migration: Com- mission Reports on Progress in Greece, Italy and the Western Balkans'. Press Release. 10 February, Brussels. Available at: http://europa.eu/rapid/press-release IP-16-269 en.htm

European Commission. 2016b. 'EU Budget for the Refugee Crisis: Fact Sheet'. 10 Febru- ary, Brussels. Available at: http://ec.europa.eu/dgs/home-affairs/what-we-do/policies/european-agenda-migration/backgroundinformation/docs/eu budget for the refugee crisis 20160210 en.pdf

European Commission. 2016c. 'Managing the Refugee Crisis. EU Support to Greece: Fact Sheet'. 5 October, Brussels. Available at: http://ec.europa.eu/dgs/home-affairs/what-we-do/policies/european-agendamigration/backgroundinformation/docs/20160928/factsheet managing refugee crisis eu financial support greece - update en.pdf

European Commission. 2016d. 'EU Support to Lebanon: Fact Sheet'. 16 March, Brussels. Available at: http://ec.europa.eu/dgs/home-affairs/what-we-do/policies/european-agenda-migration/backgroundinformation/docs/20160316/eu support to lebanon - latest update en.pdf

European Commission. 2016e. 'Managing the Refugee Crisis: The Facility for Refugees in Turkey: Fact Sheet'. 28 September, Brussels. Available at: http://ec.europa.eu/dgs/home-affairs/what-we-do/policies/european-agendamigration/background-information/docs/20160928/factsheet frit factsheet en.pdf

European Commission. 2016f. 'Establishing a Union Resettlement Framework and Amending Regulation (EU) $N^{\circ} 516 / 2014$ of the European Parliament and the Council'. COM2016/468 final. 13 July, Brussels. Available at: http://ec.europa.eu/dgs/home-affairs/what-we-do/policies/european-agenda-migration/proposal-implementationpackage/docs/20160713/resettlement system en.pdf

European Commission. 2016g. 'Third Report on the Progress Made in the Implementation of the EU-Turkey Statement'. $\operatorname{COM}(2016) 634$ final. 28 September, Brussels. Available at: http://ec.europa.eu/dgs/home-affairs/what-wedo/policies/european-agenda-migration/proposal-implementation-

package/docs/20160928/3rd report on the progress made in the implementation of the euturkey statement en.pdf

European Council. 1999. 'Presidency Conclusion'. 15-16 October, Tampere. Available at: www.europarl.europa.eu/summits/tam en.htm\#c

European Council. 2005a. 'The Hague Programme: Strengthening Freedom, Security and Justice in the European Union'. 2005/C 53/01. 2 March. Available at: http://eur-lex.europa.eu/legalcontent/EN/TXT/PDF/?uri=CELEX:52005XG0303(01)\&from=IT

European Council. 2005b. 'A Strategy for the External Dimension of JHA: Global Freedom, Security and Justice'. 14366/03/05 REV 3, JAI 417. 30 November, Brussels. Available at: http://register.consilium.europa.eu/doc/srv?|=EN\&f=ST\%2014366\%202005\%20REV\%203

European Council. 2005c. 'The European Union Counter-Terrorism Strategy'. 14469/04/05 REV 3, JAI 423. 30 November, Brussels. Available http://register.consilium.europa.eu/doc/srv?|=EN\&f=ST\%2014469\%202005\%20REV\%204

European Council. 2008a. 'European Pact on Immigration and Asylum'. 13440/08 ASIM 68. 24 September, Brussels. Available at: http://register.consilium.europa.eu/doc/srv?|=EN\&f=ST\%2013440\%202008\%20INIT 
European Council. 2008b. 'Report on the Implementation of the European Security Strategy - Providing Security in a Changing World'. S407/08. 11 December, Brussels. Available at: www.consilium.europa.eu/ueDocs/cms Data/docs/pressdata/EN/reports/104630.pdf

European Council. 2009. 'The Stockholm Programme - An Open and Secure Europe Serving and Protecting the Citizens.' 1724/09 JAl 896. 2 December, Brussels. Available at: https:/lec.europa.eu/antitrafficking/sites/antitrafficking/files/the stockholm programme - an open and secure europe en 1.pdf

European Council. 2016a. 'European Council Conclusions'. 17-18 March, Brussels. Available at: www.consilium.europa.eu/en/meetings/european-council/2016/03/17-18/.

European Council. 2016b. 'EU-Turkey Statement, 18 March 2016'. Press Release. 18 March, Brussels. Available at: www.consilium.europa.eu/en/press/press-releases/2016/03/18-eu-Turkey-statement/

Guild, Elspeth. 2003. 'International Terrorism and EU Immigration, Asylum and Borders Policy: The Unexpected Victims of 11 September 2001'. European Foreign Affairs Review, 8 (3): 331-346.

Jeandesboz, Julien and Polly Pallister-Wilkins. 2016. 'Crisis, Routine, Consolidation: The Politics of the Mediterranean Migration Crisis'. Mediterranean Politics, 21 (2): 316-320. doi:10.1080/13629395.2016.1145825.

Juncker, Jean-Claude. 2014. 'Political Guidelines for the Next European Commission: A New Start for Europe: My Agenda for Jobs, Growth, Fairness and Democratic Change'. Opening Statement in the European Parliament Plenary Session. 15 July, Strasbourg.

Kaunert, Christian. 2005. 'The Area of Freedom, Security and Justice: The Construction of a "European Public Order" '. European Security, 14 (4): 459-483. doi:10.1080/09662830500528161.

Lavenex, Sandra and Nicole Wichmann. 2009. 'The External Governance of EU Internal Security'. Journal of European Integration, 31 (1): 83-102. doi:10.1080/07036330802503932.

Léonard, Sarah. 2010. 'EU Border Security and Migration into the European Union: FRONTEX and Securitisation Through Practices'. European Security, 19 (2): 231-254. doi:10.1080/09662839.2010.526937.

Longo, Francesca. 2013. 'Justice and Home Affairs as a New Dimension of the European Security Concept'. European Foreign Affairs Review, 18 (1): 29-46.

Lucarelli, Sonia and Ian Manners. 2006. Values and Principles in European Foreign Policy. London: Routledge.

Maurice, Eric. 2015. 'France and Commission Push to Fortify Schengen'. EU Observer, 18 November. Available at: https://euobserver.com/justice/131165

Monar, Jörg. 2006. 'Justice and Home Affairs'. JCMS: Journal of Common Market Studies, 44(Annual Review): 101-117. doi:10.1111/j.1468-5965.2006.00647.x.

Neal, Andrew. 2009. 'Securitization and Risk at the EU Border: The Origins of FRONTEX'. JCMS: Journal of Common Market Studies, 47 (2): 333-356. doi:10.1111/j.1468-5965.2009.00807.

Nielsen, Nikolaj. 2016a. 'Austria Curtails Asylum Rights'. EU Observer, 28 April. Available at: https://euobserver.com/migration/133247.

Nielsen, Nikolaj. 2016b. 'EU Migrant Route Now Twice as Deadly'. EU Observer, 2 August. Available at: https://euobserver.com/migration/134555.

Rettman, Andrew. 2016. 'Poland: Middle East Migrants Cause EU Tensions'. EU Observer, 4 April. Available at: https://euobserver.com/migration/132881.

Traub, James. 2016. 'The Death of the Most Generous Nation on Earth'. Foreign Policy, 10 February. Available at: http://foreignpolicy.com/2016/02/10/the-death-of-the-most- generous-nation-on-earth-sweden-syria-refugee-europe/.

Travis, Alan. 2014. 'UK Axes Support for Mediterranean Migrant Rescue Operation'. Guardian, 27 October. Available at: www.theguardian.com/politics/2014/oct/27/uk-mediterranean-migrant-rescue-plan.

Vito, Elio. 2015. Resoconto dell'Assemblea. XII Legislatura. Italian Chamber of Deputies. 30 July, Rome.

Zalan, Eszter. 2015. 'Hungary Rejects EU Offer to Take Refugees.' EU Observer, 11 September. Available at: https://euobserver.com/migration/130217.

Zalan, Eszter. 2016. 'Stakes Grow in Hungary's Migration Referendum.' EU Observer, 7 July. Available at: https://euobserver.com/political/134231. 